Vol. 24, No. 4, pp $24-35$, Year 2019

\title{
Chemical study of some species related to the Malvaceae family that growing in the Al-Diwaniya Governorate
}

\author{
Hussein Ali Kadhim AL-Aridhee Suhaila Hussein Baji Al-Lami Safa Ayad Jassim \\ Department of Biology, Faculty of Education, University of AL-Qadisiyah \\ Corresponding author: nmnmnn895@gmail.com
}

\begin{abstract}
The present study dealt with the chemical content of the leaves extract of six species from Malvaceae family in ALDiwaniyah governorate, where all species are present in it. Its: Hibiscus sabdariffa (L.), Abelmoschus esculentus (L.), Moench Althaea ludwigii (L.), Malva parviflora (L.) and Gossypium hirsutum (L.). Chemical compounds were identified using the GC-MASS gas chromatography technique.

The results showed that these species contained several secondary metabolites, which included phenols, turbines, alkaloids, kanates, esters and steroids. The presence of some compounds involved more than one species, which helped isolate the species from each other, such as the 2-Pentenal compound, 5-phenyl, found in the extract of the leaves $A b$. esculentus and Al. ludwigii and the compound Benzene, 1,2,1 - (1,2-cyclobutanediyl) bis-, cis- which was found in all species under study except $M$. parviflora.

It was observed through the study that the two genus Hibiscus contained the most common compounds by six compounds supported their return to the same genus, as for compound Styrene was presence in all species.
\end{abstract}

The species were also distinguished by other compounds such as 10-Undecyn-1-ol and Z-4-Dodecenol, which were found in Al. ludwigii and H. rosa-sinensis, which enhanced the taxonomic importance of this study.

Key words: Malvaceae, Chemotaxonomy, Effective chemicals.

\section{Introduction}

The Malvaceae family is one of the largest and most advanced families, consisting of 85 species and 1,500 species, The genus of Hibiscus is one of the largest genera of the family, consisting of 300 species (Jongbloed, 2003). Stevens (2012) has reported that the family consists of 243 genus and 4335 species. In Iraq, there are about 21 wild species and 12 cultivated species (Al-Mousawi, 1987). The science of classification often interferes with other science such as ecology, genetics, biochemistry and others, the modern science that is 


\section{Al-Qadisiyah Journal Of Pure Science (QJPS)}

Vol. 24, No. 4, pp $24-35$, Year 2019

based on the identification of effective chemicals in plants to differentiate them, as well as used by the herb in the treatment of many diseases that cannot be complex and processed medicines to treat them (AlQubaisi, 2004).

Secondary metabolites are compounds used by humans in many aspects, both pharmaceutical and industrial, the great advances in chemistry have helped to easily separate active substances in plants for use (Morton et al., 2000).

These secondary compounds are produced in the plant in varying quantities because they are believed to be produced for defensive purposes, may use them to resist insects and have a role in maintaining and adapting the plants to the environment in which they are present, also some plants need to attract insects for pollination by producing volatile oils in their flowers (Kliebenstein, 2004). The broad pharmacological benefits of these compounds have increased the focus on methods of extraction, paving the way for their physiological and therapeutic effectiveness with reduced toxicity (Manna and Abalaka, 2000).

Many studies have shown the chemical composition of the Malvaceae family around the world that secondary

\section{Materials and Methods}

2.1.Preparation of extracts of raw chemical compounds

- The experiment was conducted in the Environmental Lab / Biology Department / College of Education / University of ALQadisiyah, the chemical compounds extracted from the powder of plant leaves according to Markham (1982) with some modification and as follows:

- $\quad$ Plant leaves were collected from the species under study at October 2017 until February 2018 and were then grind separately by the electric grinder to obtain a soft mixture after washing and drying at room temperature, then kept in plastic containers until use.

- $\quad$ Mix up $1 \mathrm{gm}$. of powder with $10 \mathrm{ml}$ of methanol $(99 \%)$ in a glass tube with continuous stirring for 10 minutes then left at room temperature and in a dark place for 12 hours. metabolites are present in all plant parts of this family and in varying amounts, they also contain antioxidants used in various industries such as cosmetics and jams (Baum et al., 2004).

The plants in the Malvaceae family are characterized by many active compounds, as Sheikh (2004) refer that the extract substance of $H$. sabdariffa contains many active compounds such as phenols also Mahadevan and Kamboj (2009) also pointed to contain the H. sabdariffa plant phenolic acids and flavonoids as well as alkaloids, terpenes and many secondary metabolites in different plant parts. While Al-Ameer et al. (2010) refer that the species $H$. sabdariffa, Al. ludwigii and $H$. rosa-sinensis to contain the anti-oxidants such as phenols, alkaloids, and Sterols, as Ammar et al. (2013) the Al. ludwigii plant contains five phenolic compounds. Chaturvedi et al., (2010) also pointed it that the Gossypium herbaceum contained many phenolic compounds such as flavonoids, glycosides, While Petkewich (2006) refers that the Al. ludwigii contained starch, pectin, flavonoids, phenolic acids. As well as Ab. esculentus considered sucrose of amino acids, vitamins, flavonoids, phenolic acids and many other chemical compounds (Temple and Gladwin, 2003)

All of the above the aim of this study uses chemical evidence to differentiate between the Malvaceae family.

- Then use a filter attached to a medical syringe with a 0.45 -micrometer slot to filter the extract in a second glass tube.

- Add $1 \mathrm{ml}$ of hexane concentration (99\%) to expel water and increase the concentration of extract.

- Chemical compounds were estimated in the extract after the withdrawal of the floating part separated from the water by hexane.

2.2.Separation and diagnosis of chemical compounds by using Gas / Chromatography / Mass Spectrometry.

- The method of technical analysis GC-MS

- The GC-MS analysis was performed using the GC Clarus 500 perkin Elmer system, which contains the gas chromatography associated with the mass spectrometer and the AOC-20i autosampler, Fig. 1, under the following conditions:

- Injector temperature $250^{\circ} \mathrm{C}$.

- Ion source temperature $280^{\circ} \mathrm{C}$. 


\section{$\because$ \\ Al-Qadisiyah Journal Of Pure Science (QJPS)}

Vol. 24, No. 4, pp $24-35$, Year 2019

- Use of helium gas $(99,999 \%)$ as a transporter gas at a continuous flow rate of $1 \mathrm{ml}$. Min -1.

- The injected liquid is $0.5 \mu \mathrm{l}$ and works at split rates $(1: 10)$.

- $\quad$ The oven temperature is $110^{\circ} \mathrm{C}$, programmed automatically at $10^{\circ} \mathrm{C}$. Minute 1 up to $200^{\circ} \mathrm{C}$ then continue to increase in temperature until it reaches $280^{\circ} \mathrm{C}$ where it stabilizes for 9 minutes until the end.

- Mass spectra were taken on a $70 \mathrm{EV}$ basis at a time interval of 0.5 seconds while the fission rate was 40 to $450 \mathrm{dl}$.

- The total time is 36 minutes of starting the GC device until it turns on.

- The separation column is an Elite-1 fused silica capillary column consisting of $100 \%$ Dimethyl Polysiloxane (100\% Dimethyl Polysiloxane), which works in the $70 \mathrm{EV}$ effect mode.

\section{Results and Discussion}

The abundance of the chemical content of the species under study was observed in quantitative and qualitative terms, with 315 compounds, varying between phenols, terpenes, alkanes, alkaloids, esters, and steroids. The species $H$. rosa-sinensis was included in 28 compounds, $H$. sabdariffa, included 40 compounds, Ab. esculentus contained 25 compounds, while Al. ludwigii had 18 compounds, while $G$. hirsutum included 20 compounds and $M$. parviflora contained 22 compounds.

Each type is distinguished by chemical compounds, giving it a significant taxonomic significance in isolating it from other species. Record 34 compounds of phenols when the species Al. ludwigii included 9 phenolic compounds, while the $H$. rosa-sinensis contained 10 phenolic compounds and separated six phenolic compounds from $G$. hirsutum leaves and $H$. sabdariffa species obtained the largest share of phenolic compounds, which reached to 12 compounds, while $A b$. esculentus included 8 phenolic compounds and $M$. parviflora contained 7 phenolic compounds. (Table 1)

As for the turbines was diagnosis 31 compounds in the leaves of species under study, also found were 3 turbine compounds in the Al. ludwigii and $H$. rosa-sinensis contained 6 terpenes, While 5 terpenes were identified in $G$. hirsutum, also $H$. sabdariffa which included amounted 11 compounds and 9 turbines were identified in the species $A b$. esculentus, while 6 compounds appeared in $M$. parviflora (Table 2).
- $\quad$ The pressure inside the device $49.5 \mathrm{kpa}$ and 1 ml. Min -1.

- $\quad$ Based on TurboMass Ver 5.2.0 for mass spectra and chromatograms, the relative amount of each component was calculated by comparing the average area of the area to Srinivasan, et al. 2013.

\subsection{Identification of chemical compounds:}

The components were determined according to GC-MS mass spectrometry, Figure 1 and the National Institute of Standards and Technology database was used with 62,000 or more known patterns. The resulting spectrum of the unknown component was compared with a range of known components stored in the NIST library to confirm the molecular weight and name, and the structure of the components of the test materials. This test was conducted in the GC-MAS/ Environment and Water Department / Ministry of Science and Technology Unit

In the case of alkanes, 29 compounds were identified in the leaves of species under study, when 4 of them were identified in the species Al. ludwigii, while 5 compounds were separated from $H$. rosa-sinensis leaf extract, in addition, six compounds were recorded in the G. hirsutum and H.sabdariffa also included 9 compounds, while 4 compounds were diagnosed in the Ab. esculentus, 4 compounds were recorded also in $M$. parviflora (Table 3 ).

The study showed the alkaloids compounds reached to 13 compounds in the leaves of species under studied were distributed between 2 compounds in the $\mathrm{Al}$. ludwigii and 3 compounds in $H$. rosa-sinensis, as for $G$. hirsutum there were only 2 compounds and the species H. sabdariffa recorded 2 compounds of alkaloids, while presence 3 compounds of alkaloids in the Ab. esculentus also diagnosed 3 compounds in $M$. parviflora (Table 4).

As for the Astra compounds, which were diagnosed 10 types of this compounds, 4 compounds were recorded in $H$. rosa-sinensis and 6 compounds in $H$. asabdariffa and The steroid compounds that were diagnosed 4 compounds in the leaves of species under study (Table $5)$.

The study also found that there were 16 compounds of the combined species between the species under study (Table 6). Some compounds were found in a species and were not found in other species or vice versa. Styrene has been present in all species under study, while the 


\section{Al-Qadisiyah Journal Of Pure Science (QJPS)}

Vol. 24, No. 4, pp $24-35$, Year 2019

composite of Benzene, 1,1'- (1,2-cyclobutanediyl) bis,cis- founded in all species except the M. parviflora, and the Glycerin compound found in all species except the Ab. esculentus and Al. ludwigii. The study also found that Hibiscus contained the most common phenolic compounds.

The study agreed with Al-Ameer et al. (2010) in the presence of phenols, alkaloids, and steroids in the leaves of Al. ludwigii, while the study did not agree with what is referred to by Ammar et al. (2013) containing the same species only five phenolic compounds, while the current study recorded nine phenolic compounds and the study agreed with Gupta et al. (2013) in the leaf of $H$. rosa-sinensis and $G$. hirsutum. The study also agreed with the Sheikh (2004) and Mahadevan and Kamboj (2009) in the presence of most secondary metabolites in the leaves of $H$. sabdariffa.

The study was consistent with what Abobaker et al., (2017) with a high percentage of phenols, terpenes, alkaloids, and esters in the leaves of the Ab. esculentus, while the study agreed with what indicated by Denton et al. (2004) in containing the Ab. esculentus on the most important turbines and vitamin $\mathrm{E}$ also agreed with both
Ahmed and Ibrahim (2016) in the presence of phenols and alkaloids in the leaves of this type.

Mohammed and al-Obaidi (1989) pointed out that the increase in plant metabolism is related to the spread of the root mass and the absorption of substances and elements that lead to the efficiency of photosynthesis process and thus increase the chemical compounds when good conditions for growth increase the process of photosynthesis and thus increase the stored compounds In the plant.

In addition, the type of compounds shown in the GCMAS analysis is significantly affected by the type of extract and extraction method (al-Maliki, 2016). Many organic solvents were used to extract chemical compounds from plants, including chloroform, methanol, acetone, hexane, and others. Methanol can be used as a solvent to obtain polar compounds such as phenols and canines using the polar separation column in the gas chromatography apparatus, hexane can be used to separate polar compounds such as turbines and esters using the non-polar column, while a general column is used to obtain both (Al-Tameme, 2017). Methanol and hexane were used in this study.

Table (1) Phenolic compounds in the species under study.

\begin{tabular}{|c|c|c|c|c|c|c|c|}
\hline \multirow[t]{2}{*}{ No. } & \multirow[t]{2}{*}{ Compound name } & \multicolumn{6}{|c|}{ Species } \\
\hline & & $\begin{array}{c}A b . \\
\text { esculentus }\end{array}$ & $\begin{array}{c}\text { Al. } \\
\text { ludwigii }\end{array}$ & $\begin{array}{c}G . \\
\text { hirsutum }\end{array}$ & $\begin{array}{l}H . \\
\text { rosa- } \\
\text { sinensis }\end{array}$ & $\begin{array}{c}H . \\
\text { sabdariffa }\end{array}$ & $\begin{array}{c}M . \\
\text { parviflora }\end{array}$ \\
\hline 1 & Cyclopropyl carbinol & - & + & - & - & - & - \\
\hline 2 & Styrene & + & + & + & + & + & + \\
\hline 3 & (3-Methyl-oxiran-2-yl)-methanol & - & + & - & - & - & - \\
\hline 4 & $\begin{array}{c}\text { 1,3-Propanediol, } 2- \\
\text { (hydroxymethyl)-2-nitro }\end{array}$ & - & + & - & - & - & + \\
\hline 5 & $\begin{array}{c}\text { Benzene, } 1,1 \text { '-(1,2- } \\
\text { cyclobutanediyl)bis-, cis- }\end{array}$ & + & + & + & + & + & - \\
\hline 6 & 10-Undecyn-1-ol & - & + & - & - & - & - \\
\hline 7 & $\begin{array}{l}\text { (2,3-Diphenylcyclopropyl)methyl } \\
\text { phenyl sulfoxide, trans }\end{array}$ & + & + & - & + & - & - \\
\hline 8 & 2-Pentenal, 5-phenyl- & + & + & - & - & - & - \\
\hline 9 & $\begin{array}{l}\text { 4-Hydroxy-8-oxo-4-phenyl-2-aza- } \\
\text { tricyclo[3.3.1.0 }(3,7)] \text { nonane-2,3- } \\
\text { dicarboxylic acid, dibenzyl ester }\end{array}$ & - & + & - & - & - & - \\
\hline 10 & Glycerin & - & - & + & + & + & + \\
\hline 11 & $\begin{array}{l}\text { 3(2H)-Furanone, dihydro-2,2- } \\
\text { dimethyl-5-phenyl- }\end{array}$ & - & - & - & + & - & - \\
\hline 12 & 1,14-Tetradecanediol & - & - & - & + & - & - \\
\hline
\end{tabular}


Vol. 24, No. 4, pp $24-35$, Year 2019

\begin{tabular}{|c|c|c|c|c|c|c|c|}
\hline 13 & Z-4-Dodecenol & - & - & - & + & - & - \\
\hline 14 & 3-Cyclohexene-1-ethanol & + & - & - & + & - & - \\
\hline 15 & 2.3 Epoxyhexanol & - & - & - & + & - & - \\
\hline 16 & $\begin{array}{c}\text { Benzene, 1,1'-[4-(3-phenylpropyl)- } \\
\text { 1,7- heptanediyl]bis- } \\
\end{array}$ & - & - & - & + & - & - \\
\hline 17 & $\begin{array}{l}\text { 4H-Pyran-4-one, 2,3-dihydro-3,5- } \\
\text { dihydroxy-6-methyl- }\end{array}$ & - & - & + & - & + & + \\
\hline 18 & Isopropyl phenyl ketone & - & - & + & - & - & - \\
\hline 19 & 1-Pentanol, 2,2,4-trimethyl- & - & - & + & - & - & - \\
\hline 20 & $\begin{array}{l}\text { 2,6,8-Trimethylbicyclo[4.2.0]oct- } \\
\text { 2-ene-1,8-diol }\end{array}$ & + & - & - & - & - & - \\
\hline 21 & $\begin{array}{l}\text { 1,2-Benzenedicarboxylic acid, } \\
\text { diisooctyl ester }\end{array}$ & + & - & - & - & - & - \\
\hline 22 & $\begin{array}{c}\text { Benzene, 1,1'-[3-(2- } \\
\text { phenylethylidene)-1,5- } \\
\text { pentanediyl]bis- }\end{array}$ & + & - & - & - & - & - \\
\hline 23 & 8-Phenyloctanoic acid & + & - & - & - & - & - \\
\hline 24 & Pentanal & - & - & - & - & + & - \\
\hline 25 & Phenol, p-(benzyloxy)-, benzoate & - & - & - & - & + & - \\
\hline 26 & 2-Furancarboxaldehyde, 5-methyl- & - & - & - & - & + & - \\
\hline 27 & Benzeneacetaldehyde & - & - & - & - & + & - \\
\hline 28 & $\begin{array}{c}\text { 2-(4a,8-Dimethyl-2,3,4,4a,5,6- } 26 \\
\text { hexahydro-naphthalen-2-yl)-prop- } \\
2- \\
\text { en-1-ol }\end{array}$ & - & - & - & - & + & - \\
\hline 29 & $\begin{array}{c}\text { 2-Furancarboxaldehyde, 5- } \\
\text { (hydroxymethyl)- }\end{array}$ & - & - & - & - & + & - \\
\hline 30 & 3-Dodecanol & - & - & - & - & + & - \\
\hline 31 & $\begin{array}{c}\text { 1,2-Propanediol, 3-benzyloxy-1,2- } \\
\text { diacetyl- }\end{array}$ & - & - & - & - & + & - \\
\hline 31 & 1-Undecanol & - & - & - & - & - & + \\
\hline 32 & 1-Hexadecanol & - & - & - & - & - & + \\
\hline 33 & $\begin{array}{l}\text { 2-Oxabicyclo[4.3.0]non-8-en-3- } \\
\text { one, 4,4-dimethyl-, cis }\end{array}$ & - & - & - & - & - & + \\
\hline
\end{tabular}

(+) The presence of a compound (-) No compound. 


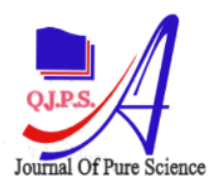

Journal Of Pure Science
Available online at http://qu.edu.iq/journalsc/index.php/JOPS

Al-Qadisiyah Journal Of Pure Science

(QJPS)

Vol. 24, No. 4, pp 24 -35, Year 2019

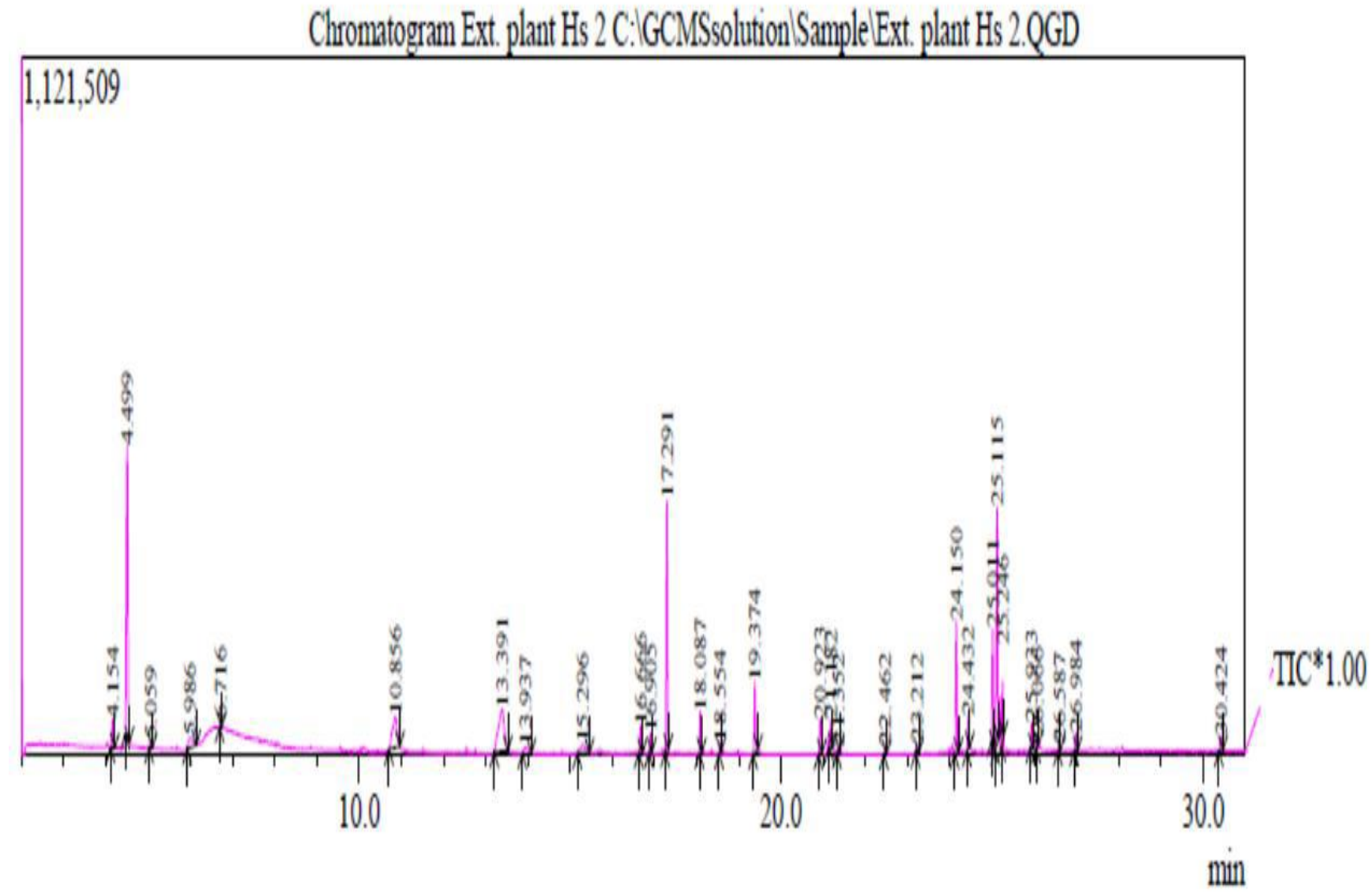

Fig.1: Chromatogram of Leaves rosa-sinensis

Table (2) Turbine compounds in the species under study

\begin{tabular}{|c|c|c|c|c|c|c|c|}
\hline \multirow[t]{2}{*}{ No. } & \multirow[t]{2}{*}{ Compound name } & \multicolumn{6}{|c|}{ Species } \\
\hline & & $\begin{array}{c}A b . \\
\text { esculentus }\end{array}$ & $\begin{array}{c}\text { Al. } \\
\text { ludwigii }\end{array}$ & $\begin{array}{c}G . \\
\text { hirsutum }\end{array}$ & $\begin{array}{c}H . \\
\text { rosa- } \\
\text { sinensis }\end{array}$ & $\begin{array}{c}H . \\
\text { sabdariffa }\end{array}$ & $\begin{array}{c}M . \\
\text { parviflora }\end{array}$ \\
\hline 1 & Butanenitrile, 3-methyl- & - & + & - & - & - & - \\
\hline 2 & Butane, 2-iodo-3-methyl & - & + & - & - & - & - \\
\hline 3 & n-Hexadecanoic acid & + & + & - & + & + & - \\
\hline 4 & Glycidyl methyl ether & - & - & - & + & - & - \\
\hline 5 & 6-Octen-1-ol, 3,7-dimethyl-, (.+/-.)- & - & - & - & + & - & - \\
\hline 6 & Isopropenyl methyl ether & - & - & - & + & - & - \\
\hline 7 & Vitamin E & + & - & - & + & + & - \\
\hline 8 & $\begin{array}{l}\text { Pentadecanoic acid, 2-hydroxy-1- } \\
\text { (hydroxymethyl)ethyl ester }\end{array}$ & - & - & - & + & - & - \\
\hline 9 & Phytol & + & - & - & - & + & + \\
\hline
\end{tabular}




\section{Al-Qadisiyah Journal Of Pure Science (QJPS)}

Vol. 24, No. 4, pp 24 -35, Year 2019

\begin{tabular}{|c|c|c|c|c|c|c|c|}
\hline 10 & $\begin{array}{l}\text { 3-Cyclohexene-1-methanol, } \\
\text {.alpha.,.alpha.,4-trimethyl-, } \\
\text { acetate }\end{array}$ & - & - & + & - & - & - \\
\hline 11 & 11-Tridecenyl propionate & - & - & + & - & - & - \\
\hline 12 & $\begin{array}{l}\text { Cyclopropane, 1,1-dimethyl-2-(2,4- } \\
\text { pentadienyl)- }\end{array}$ & - & - & + & - & - & - \\
\hline 13 & $\begin{array}{l}\text { Disulfide, (1-methylethyl) (1,1- } \\
\text { dimethylethyl) }\end{array}$ & - & - & + & - & - & - \\
\hline 14 & $\begin{array}{l}\mathrm{N} \text {-[Carboxymethyl]maleamic acid } \\
\text { dimethyl ester }\end{array}$ & - & - & - & - & + & - \\
\hline 15 & Citronellyl isobutyrate & - & - & - & - & + & - \\
\hline 16 & $\begin{array}{l}\text { Pentadecanoic acid, 14-methyl-, methyl } \\
\text { ester }\end{array}$ & - & - & - & - & + & - \\
\hline 17 & 11,14-Eicosadienoic acid, methyl ester & - & - & - & - & + & - \\
\hline 18 & $\begin{array}{l}8,11,14-\text { Docosatrienoic acid, methyl } \\
\text { ester }\end{array}$ & - & - & - & - & + & - \\
\hline 19 & cis-13,16-Docasadienoic acid & - & - & - & - & + & - \\
\hline 20 & cis,cis,cis-7,10,13-Hexadecatrienal & - & - & - & - & + & + \\
\hline 21 & $\begin{array}{l}\text { Eicosanoic acid, 2-hydroxy-1- } \\
\text { (hydroxymethyl)ethyl ester }\end{array}$ & - & - & - & - & + & - \\
\hline 22 & $\begin{array}{l}\text { Hexadecanoic acid, 15-methyl-, methyl } \\
\text { ester }\end{array}$ & + & - & - & - & - & - \\
\hline 23 & cis,cis-7,10,-Hexadecadienal & + & - & - & - & - & - \\
\hline 24 & Eicosanoic acid & + & - & - & - & - & - \\
\hline 25 & $\begin{array}{l}\text { Hexadecanoic acid, 2-hydroxy-1- } \\
\text { (hydroxymethyl)ethyl ester }\end{array}$ & + & - & - & - & - & - \\
\hline 26 & $\begin{array}{l}\text { Octadecanoic acid, 2,3- } \\
\text { dihydroxypropyl ester }\end{array}$ & + & - & - & - & - & - \\
\hline 27 & gamma.-Tocopherol & + & - & - & - & - & - \\
\hline 28 & $\begin{array}{c}\text { 3,7,11,15-Tetramethyl-2-hexadecen-1- } \\
\text { ol }\end{array}$ & - & - & - & - & - & + \\
\hline 29 & Pentadecanoic acid & - & - & - & - & - & + \\
\hline 30 & $\begin{array}{l}\text { 11,14,17-Eicosatrienoic acid, methyl } \\
\text { ester }\end{array}$ & - & - & - & - & - & + \\
\hline 31 & $\begin{array}{l}\text { Fumaric acid, 2-dimethylaminoethyl } \\
\text { nonyl ester }\end{array}$ & - & - & - & - & - & + \\
\hline
\end{tabular}

(+) The presence of a compound (-) No compound

Table (3) Spinal compounds in the species under study

\begin{tabular}{|c|c|c|c|c|c|c|c|}
\hline \multirow[t]{2}{*}{ No. } & \multirow[t]{2}{*}{ Compound name } & \multicolumn{6}{|c|}{ Species } \\
\hline & & $\begin{array}{c}\text { Ab. } \\
\text { esculentus }\end{array}$ & $\begin{array}{c}\text { Al. } \\
\text { ludwigii }\end{array}$ & $\begin{array}{c}G . \\
\text { hirsutum }\end{array}$ & $\begin{array}{c}H . \\
\text { rosa- } \\
\text { sinensis }\end{array}$ & $\begin{array}{c}H . \\
\text { sabdariffa }\end{array}$ & $\begin{array}{c}\text { M. } \\
\text { parviflora }\end{array}$ \\
\hline 1 & 3-Hepten-2-one & - & + & - & - & - & - \\
\hline 2 & Eicosane & - & + & - & - & - & - \\
\hline 3 & N-Acetylisoxazolidine & - & + & - & - & - & - \\
\hline 4 & $\begin{array}{l}\text { Formazine, 1,5-diphenyl-3-(5- } \\
\text { nitrofuran-2-yl)- }\end{array}$ & - & + & - & - & - & - \\
\hline 5 & p-Xylene & + & - & - & + & - & - \\
\hline 6 & 2-Cyclopenten-1-one, 2-hydroxy- & - & - & - & + & - & - \\
\hline 7 & Oxirane, (propoxymethyl)- & - & - & - & + & - & - \\
\hline 8 & 1,3,5-Cycloheptatriene, 7-ethyl- & - & - & - & + & - & - \\
\hline
\end{tabular}


Vol. 24, No. 4, pp $24-35$, Year 2019

\begin{tabular}{|c|c|c|c|c|c|c|c|}
\hline 9 & 2,6-Octadiene, 4,5-dimethyl- & - & - & - & + & - & - \\
\hline 10 & Furfural & - & - & + & - & + & - \\
\hline 11 & N-Ethyl-2-carbomethoxyazetidine & - & - & - & - & + & - \\
\hline 12 & 1-Tetradecene & - & - & - & - & + & - \\
\hline 13 & Oxirane, (butoxymethyl)- & - & - & - & - & + & - \\
\hline 14 & Octane, 1-(1-ethoxyethoxy)- & - & - & - & - & + & - \\
\hline 15 & $\begin{array}{c}\text { 5,7-Octadien-3-ol, 2,4,4,7-tetramethyl-, } \\
\text { (E)- }\end{array}$ & - & - & - & - & + & - \\
\hline 16 & Nonyl trifluoroacetate & - & - & - & - & + & - \\
\hline 17 & $\begin{array}{c}\text { 2,6,10,14,18,22-Tetracosahexaene, } \\
\text { 2,6,10,15,19,23-hexamethyl-, (all-E)- }\end{array}$ & - & - & - & - & + & - \\
\hline 18 & Oxetane, 3-(1-methylethyl)- & - & - & + & - & - & - \\
\hline 19 & 4-Hexen-3-one, 4,5-dimethyl- & - & - & + & - & - & - \\
\hline 20 & 5-Nonen-4-one, 6-methyl- & - & - & + & - & - & - \\
\hline 21 & Octane, 4-bromo- & - & - & + & - & - & - \\
\hline 22 & 1,8-Nonadiyne & - & - & + & - & - & - \\
\hline 23 & 2-Decene, 8-methyl-, (Z)- & + & - & - & - & - & - \\
\hline 24 & 1-Pentadecyne & + & - & - & - & - & - \\
\hline 25 & 2-Methylbicyclo[3.2.1]octane & + & - & - & - & - & - \\
\hline 26 & Oxetane, 2-methyl-4-propyl & - & - & - & - & - & + \\
\hline 27 & 5-Octen-1-ol, (Z)- & - & - & - & - & - & + \\
\hline 28 & (R)-(-)-(Z)-14-Methyl-8-hexadecen-1-ol & - & - & - & - & - & + \\
\hline 29 & Oxirane, [(dodecyloxy)methyl]- & - & - & - & - & - & + \\
\hline
\end{tabular}

(+) The presence of a compound (-) No compound

Table (4) alkaloids compounds in the species under study.

\begin{tabular}{|c|c|c|c|c|c|c|c|}
\hline \multirow[t]{2}{*}{ No. } & \multirow[t]{2}{*}{ Compound name } & \multicolumn{6}{|c|}{ Species } \\
\hline & & $\begin{array}{c}A b . \\
\text { esculentus }\end{array}$ & $\begin{array}{c}\text { Al. } \\
\text { ludwigii }\end{array}$ & $\begin{array}{c}G . \\
\text { hirsutum }\end{array}$ & $\begin{array}{c}H . \\
\text { rosa- } \\
\text { sinensis }\end{array}$ & $\begin{array}{c}H . \\
\text { sabdariffa }\end{array}$ & $\begin{array}{c}M . \\
\text { parviflora }\end{array}$ \\
\hline 1 & $\begin{array}{l}\text { 3,3-Dimethyl-4-phenylamino-butan-2- } \\
\text { one }\end{array}$ & - & + & - & - & - & - \\
\hline 2 & $\begin{array}{c}\text { 4-Benzyloxy.beta.-methyl-.beta.- } \\
\text { nitrostyrene }\end{array}$ & - & + & - & - & - & - \\
\hline 3 & Butanoic acid & - & - & - & + & - & - \\
\hline 4 & $\begin{array}{l}\text { 4-Benzyloxy-3-methoxy-2-nitrobenzoic } \\
\text { acid }\end{array}$ & - & - & - & + & - & - \\
\hline 5 & Butanamide, 3,3-dimethyl- & - & - & + & + & - & - \\
\hline 6 & 3-Butenoic acid, ethyl ester & - & - & + & - & - & - \\
\hline 7 & Butanoic acid, 2-oxo- & - & - & - & - & + & - \\
\hline 8 & 3-Eicosyne & - & - & - & - & + & - \\
\hline 9 & 9-Octadecenamide, $(\mathrm{Z})$ - & + & - & - & - & - & + \\
\hline 10 & $\begin{array}{l}\text { Hydrazinecarboxamide, } 2-(2- \\
\text { methylcyclohexylidene }\end{array}$ & + & - & - & - & - & - \\
\hline 11 & $\begin{array}{c}\text { Ethanone, 2-(2-benzothiazolylthio)-1- } \\
\text { (3,5-dimethylpyrazolyl)- } \$ \$\end{array}$ & + & - & - & - & - & - \\
\hline 12 & 2(1H)-Pyrimidinone, 5-methyl- & - & - & - & - & - & + \\
\hline 13 & 9,12,15-Octadecatrienoic acid, (Z,Z,Z)- & - & - & - & - & - & + \\
\hline
\end{tabular}

$(+)$ The presence of a compound (-) No compound 


\section{Al-Qadisiyah Journal Of Pure Science (QJPS)}

Vol. 24, No. 4, pp $24-35$, Year 2019

Table (5) Astro - compounds in the species under study

\begin{tabular}{|c|c|c|c|c|c|c|c|}
\hline \multirow[t]{2}{*}{ No. } & \multirow{2}{*}{ Compound name } & \multicolumn{6}{|c|}{ Species } \\
\hline & & $\begin{array}{c}A b . \\
\text { esculentus }\end{array}$ & $\begin{array}{c}\text { Al. } \\
\text { ludwigii }\end{array}$ & $\begin{array}{c}G . \\
\text { hirsutum }\end{array}$ & $\begin{array}{c}H . \\
\text { rosa- } \\
\text { sinensis }\end{array}$ & $\begin{array}{c}H . \\
\text { sabdariffa }\end{array}$ & $\begin{array}{c}M . \\
\text { parviflora }\end{array}$ \\
\hline 1 & Oxalic acid, cyclobutyl heptyl ester & - & - & - & + & - & - \\
\hline 2 & Oxalic acid, cyclobutyl ethyl ester & - & - & - & + & - & - \\
\hline 3 & Oxalic acid,ethel neopentyl ester & - & - & - & + & - & - \\
\hline 4 & $\begin{array}{l}\text { Propanoic acid, 2-hydroxy-2-methyl-, } \\
\text { methyl ester }\end{array}$ & - & - & - & - & + & - \\
\hline 5 & 3-Heptenoic acid, methyl ester & - & - & - & - & + & - \\
\hline 6 & Cyclopentanecarboxylic acid, heptyl ester & - & - & - & - & + & - \\
\hline 7 & $\begin{array}{l}\text { Butanedioic acid, 3-hydroxy-2,2- } \\
\text { dimethyl-, dimethyl ester, (R)- }\end{array}$ & - & - & - & - & + & - \\
\hline 8 & n-Butyric acid 2-ethylhexyl ester & - & - & - & - & + & - \\
\hline 9 & $\begin{array}{l}\text { [1,1'-Bicyclopropyl]-2-octanoic acid, 2'- } \\
\text { hexyl-, methyl ester }\end{array}$ & - & - & - & - & + & - \\
\hline
\end{tabular}

(+) The presence of a compound (-) No compound

Table (6) Steroid compounds in the species under study.

\begin{tabular}{|c|c|c|c|c|c|c|c|}
\hline \multirow[t]{2}{*}{ No. } & \multirow[t]{2}{*}{ Compound name } & \multicolumn{6}{|c|}{ Species } \\
\hline & & $\begin{array}{c}A b . \\
\text { esculentus }\end{array}$ & $\begin{array}{c}\text { Al. } \\
\text { ludwigii }\end{array}$ & $\begin{array}{c}G . \\
\text { hirsutum }\end{array}$ & $\begin{array}{c}H . \\
\text { rosa- } \\
\text { sinensis }\end{array}$ & $\begin{array}{c}H . \\
\text { sabdariffa }\end{array}$ & $\begin{array}{c}M . \\
\text { parviflora }\end{array}$ \\
\hline 1 & n-Decanoic acid & - & - & + & - & - & - \\
\hline 2 & Fucosterol & + & - & - & - & - & - \\
\hline 3 & Ethyl iso-allocholate & - & - & - & - & - & + \\
\hline 4 & $\begin{array}{c}\text { Cholestane, 4,5-epoxy-, } \\
\text { (4.alpha.,5.alpha.)- }\end{array}$ & - & - & - & - & - & + \\
\hline
\end{tabular}

(+) The presence of a compound (-) No compound. 


\section{Al-Qadisiyah Journal Of Pure Science}

(QJPS)

Vol. 24, No. 4, pp 24-35, Year 2019

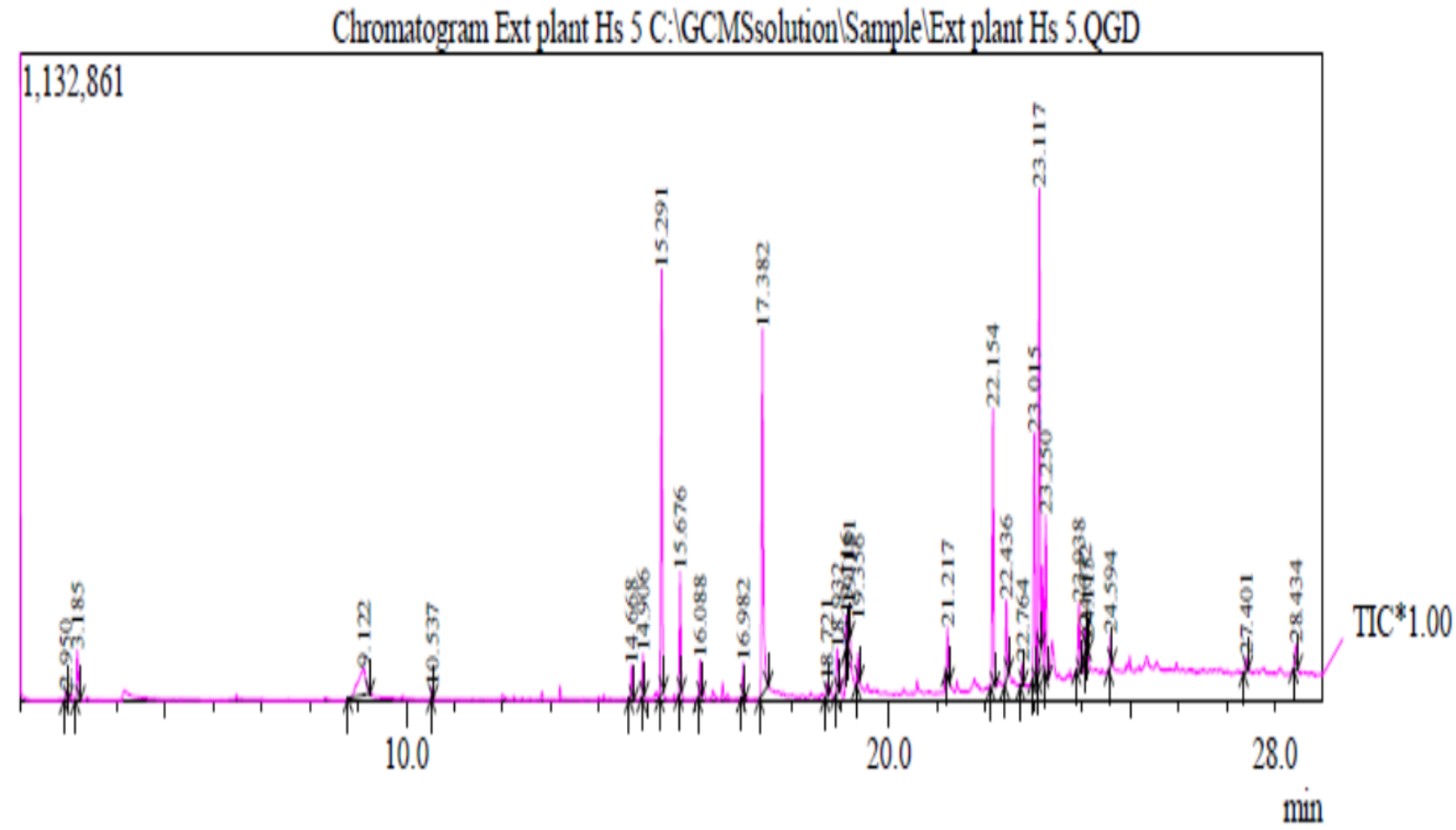

Fig.2: Chromatogram of Leaves Ab.esculentus 


\section{Al-Qadisiyah Journal Of Pure Science (QJPS)}

Vol. 24, No. 4, pp $24-35$, Year 2019

\section{- Refrences}

- Abobaker, D. M., Edrah, S. M., and Altwair, K.(2017) Phytochemical Screening of Abelmoschus esculentus From Leptis area at Al-Khums Libya. development, 17(18), 19.

- $\quad$ Ahmed, Suad Khudair and Diaa Khalil Ibrahim, (2016) Effect of adding powdered leaves of baker's plant mallow (Malva parviflora L.) to the deep in the qualities of phosphoric and productive performance For the Japanese quail birds .. Anbar Journal of Veterinary Sciences, Volume (9) Issue (1): 11-13

- $\quad \mathrm{Al}$ - Maliki, Raffal Abdul - Hussain Rassin (2016). Studying the effect of extraction methods on oil components For some of the seeds of the tent family using MSG - MS Faculty of Agriculture / University of Basra. Iraq, p. 35.

- Al-Ameer, M., Yehia, W., and Saad, I. (2010). Evaluation of Some Cotton Genotypes for Ability to Infestation Tolerance to Bollworms for Improving of Some Important Economical Characters. J. Agric. Res, 36(2), 147-169.

- Al-Mousawi, Ali Hussein Issa (1987). Classification of plants. First Edition. Faculty of Science / University Baghdad, Iraq 379 pages

- Al-Qubaisi, Han (2004). Dictionary of Herbs and Medicinal Plants Dar al Kuttab al-Sultari, Beirut, Lebanon, 565 pages

- Al-Tameme, H. J. M. (2017). Chemical profiles as chemotaxonomic tools for some species in Fabaceae in Iraq. Al-Qadisiyah Journal Of Pure Science, 20(1), 88-99.

- Ammar, N. M., El-Kashoury, E.-S. A., ElKassem, L. T. A., and El-Hakeem, R. E. A. (2013). Evaluation of the phenolic content and antioxidant potential of Althaea rosea cultivated in Egypt. Journal of The Arab Society for Medical Research, 8(2), 48.

- Baum, D. A., DeWitt Smith, S., Yen, A., Alverson, W. S., Nyffeler, R., Whitlock, B. A., and Oldham, R. L. (2004). Phylogenetic relationships of Malvatheca (Bombacoideae and Malvoideae; Malvaceae sensu lato) as inferred from plastid DNA sequences. American Journal of Botany, 91(11), 18631871.
- Chaturvedi, A., Singh, S., and Nag, T. (2010). Antimicrobial activity of flavonoids from in vitro tissue culture and seeds of Gossypium species. Romanian biotechnological letters, 15(1), 4959-4963.

- Denton, O., Schippers, R., and Oyen, L. (2004). Plant resources of tropical Africa, 2: Vegetables: Backhuys Publishers, Netherlands/CTA, Wageningen.

- Drozdova, I., and Bubenchikov, R. (2005). Composition and antiinflammatory activity of polysaccharide complexes extracted from sweet violet and low mallow. Pharmaceutical Chemistry Journal, 39(4), 197-200.

- Fuleki, T., Ricardo, d. S., and Jorge, M. (1997). Catechin and procyanidin composition of seeds from grape cultivars grown in Ontario. Journal of Agricultural and Food Chemistry, 45(4), 1156-1160.

- Jongbloed, M., Feulner, G., Böer, B., and Western, A. R. (2003). The comprehensive guide to the wild flowers of the United Arab Emirates: Environmental Research and Wildlife Development Agency.

- Kliebenstein, D. (2004). Secondary metabolites and plant / environment interactions: a view through Arabidopsis thaliana tinged glasses. Plant, Cell and Environment, 27(6), 675-684.

- Mahadevan, N., and Kamboj, P. (2009). Hibiscus sabdariffa Linn.-an overview.

- Manna, A., and Abalaka, M. (2000). Preliminary screening of the various extracts of Physalis angulata (L.) for antimicrobial activities. Spectrum J, 7(2), 119-125.

- Markham,K.R.(1982). Techniques of Flavonoid Identification 'Acad. Press، London، 1.

- Mohammed, Abdel Azim Kazem, Yunus, Moayad Ahmed. (1991). Basics of Plant Physiology. Dar al-Hikma For printing and publishing. University of Baghdad, Iraq Pages 394.

- Morton, L. W., Caccetta, R. A. A., Puddey, I. B., and Croft, K. D. (2000). Chemistry and biological effects of dietary phenolic compounds: relevance to cardiovascular disease. Clinical and Experimental 


\section{Al-Qadisiyah Journal Of Pure Science (QJPS)}

Vol. 24, No. 4, pp 24-35, Year 2019

Pharmacology and Physiology, 27(3), 152-

159.

- Petkewich, R. (2006). Marshmallow. Chemical and Engineering News, 84(16), 41-41.

- Savithramma, N., Rao, M. L., and Suhrulatha, D. (2011). Screening of medicinal plants for secondary metabolites. Middle-East Journal of Scientific Research, 8(3), 579-584.

- Sheikh, and Wafaa Mohammed Sharif(2004). Effect of Number of Irrigation and Spraying with Guillotine Extract in Growth And the plant of the cattle. Master Thesis . College of Science. University of Babylon - Iraq

- Srinivasan, k; Sivasubramanian, S. and kumaravel, S.(2013). Phytochemical profiling and GC-MS study of Adhatoda vasica leaves. Int J Pharm BioSci.5(1):714720.

- Stevens, P. F. (2012). Angiosperm Phylogeny. htt://www.Mobot.org.

- $\quad$ Temple, N. J., and Gladwin, K. K. (2003). Fruit, vegetables, and the prevention of cancer: research challenges. Nutrition, 19(5), 467-470. 